\title{
Methane fermentation as a possibility of utilization and energy - efficient management of sewage sludge
}

\author{
Anna Smurzyńska ${ }^{1 *}$, Kamil Kozłowski ${ }^{1}$, Marta Cieślik $^{2}$, Michał Brzoski ${ }^{1}$, Dawid Chełkowski ${ }^{1}$, Jakub Mazurkiewicz ${ }^{1}$ and \\ Ewa Woźniak ${ }^{1}$ \\ ${ }^{1}$ Poznan University of Life Sciences, Institute of Biosystems Engineering, Wojska Polskiego 50, 60-637 Poznan, Poland \\ ${ }^{2}$ Poznan University of Life Sciences, Department of Biotechnology and Food Microbiology, Wojska Polskiego 48, 60-637 Poznan, \\ Poland
}

\begin{abstract}
Sewage sludge contains organic and biogenic substances that should be used. These materials may also contain toxic substances and heavy metals, and therefore require proper management in accordance with applicable law. Sewage sludge disposal is important for the protection of the environment, but also for the costs associated with the disposal of sludge. There are many technologies that are designed to use the properties of sewage sludge. It should be emphasized, however, that the proposed sewage sludge management technologies require investment outlays. In the present situation, research experiments have been carried out in the Environmental Technology Laboratory of the University of Environmental and Life Sciences in Poznan, indicating the possibility of efficient use of sewage sludge in the methane fermentation process. The use of sewage sludge in the fermentation mix allows the fertilizer to be obtained in the form of fermentation pulp, which also has the same properties as natural fertilizers. It should also be noted that the effect of physicochemical changes is the production of biogas, which is the source of electricity and/or heat. The economic sustainability of the use of sludge (taking into account the current costs of their disposal) is unequivocally positive when co-fermented in an appropriate proportion. The results show that sewage sludge can be successfully used in biogas plants as a co-substrate of fermentation mix. Therefore, the use of sewage sludge in biogas plants not only allows for the safe management and production of fertilizers, but also for the "green" energy.
\end{abstract}

\section{Introduction}

Biodegradable waste is a serious environmental hazard. Bearing in mind the protection of ecosystems, biodegradable waste require a rational economy. Examples may be studies showing the possibility of utilizing unsuitable plants from hybrid sewage plants for energy purposes [12]. Applicable law provides for a number of regulations on the proper management of waste from agriculture but also from industry. As indicated by data, there is a lack of interest and technological possibilities of using organic waste as a material for the production of other products. That is why a large part is stored or subjected to selected treatments for their further agricultural use [2].

In particular animal feces require proper management. They are produced in large quantities during intensive livestock production, which is present all over the world. Studies indicate that their improper management leads to contamination of soil but also to groundwater and surface waters [18]. This is due to accumulation in high concentrations of macro-contents especially nitrogen, but also from the presence of heavy metals, which poses a serious threat to the environment, animals and people [16,23,24]. In addition to livestock

*Corresponding author: anna.smurzynska@up.poznan.pl buildings, but also in the storage or use of animal manure, emissions of greenhouse gases and odors are generated [5]. Appropriate manure and manure management is governed by construction law specifying the way they are stored. On the other hand, their use is determined by the Fertilizer and Fertilizing Act or the Code of Good Agricultural Practices.

Another sludge that requires proper management is sewage sludge, the amount of which increases with the natural increase. This substrate has a high level of organic and biogenic substances, which makes its agricultural use as fertilizer or for the restoration of green areas is a good solution [13]. However, sludge from sewage treatment plants also contain toxic substances and heavy metals, pathogenic bacteria and viruses, and parasite eggs, which according to law requires their proper disposal of $[9,10,14,22]$. It should be stressed that since 2016 the legal regulations prohibiting the deposition of sewage sludge have been successfully implemented since 2016 [19]. In view of the situation, they are looking for possibilities of their development, which will allow them to use their properties and at the same time to neutralize harmful effects on the environment. The most commonly used solution is liming or burning, which effectively helps to 
neutralize the hazards of sewage sludge. However, heat treatment involves other hazards, namely the emission of dangerous gases, including sulfur and nitrogen oxides [3].

However, it is stressed that the use of the mentioned processing of the onerous substrate requires high expenditure on the operation. In view of this, another possible technology is to subject the sludge to methane fermentation. The use of this technology not only allows us to dispose of the onerous substrate but also to produce electricity and/or heat [8]. In addition, as shown by methane fermentation studies, the resulting fermentation pulp exhibits very good fertilizer properties without compromising the environment as opposed to raw slurry or sludge $[6,7]$.

The aim of this work was to carry out the process of fermentation of sewage sludge. This allowed us to indicate their biogas and methane yield, which is to confirm the potential for utilization of the substrate and to indicate the cost-effectiveness of using sewage sludge in an anaerobic process.

\section{Materials and methodology}

\subsection{Sewage sludge used in the experiment}

The research material was sewage sludge which came from domestic wastewater treatment plant located in Wielkopolska. In order to test the biogas and methane yield of the selected substrate, a fermentation broth containing the desired microbial groups was required. In the experiment, it was a warm separated fraction of fermentation pulp from one properly functioning agricultural biogas plant. Samples were prepared with accuracy $0.5 \mathrm{~g}$. All samples needed to be analyzed in respect to the correct chemical and physical parameters. This was indispensable to calculate the contents in mixture (sewage sludge + innoculum). The $\mathrm{pH}$ was measured using laboratory multi-meter CP-411 (Elmetron). Moreover, dry matter and organic dry matter were determined. It was necessary to calculate biogas production efficiency in following units $-\mathrm{m}^{3} / \mathrm{t}$ of dry matter in normal conditions.

In the experiment the following standard methodology established by Polish Norms (PN) has been used: $\mathrm{pH}$ - PN-90 C-04540/01, dry matter PN-75 C-04616/01 and organic dry matter PN-Z-15011-3.

\subsection{Place of research and research station}

The study was conducted in Laboratory of Eco technologies - the biggest biogas laboratory in Poland, working within the Institute of Biosystems Engineering. The experimental methods have based on modified German standard DIN 38 414, while physical and chemical analytical methods based on Polish Standard System [11]. The analytical procedures concerning biowaste were also developed within several scientific projects financed within EU 6th Framework Program and Polish Ministry of Science and Higher Education in the years 2006-12.

The experiment of biogas production was conducted through anaerobic digestion in the set of fermentation chamber (Figure 1). Samples were tested in three replications. This biofermentor is commonly used for testing biogas and biomethane production efficiency.

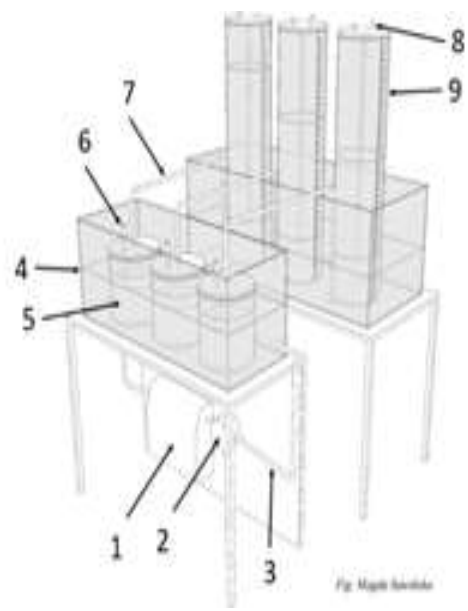

Fig. 1. Scheme of biofermentor for biogas production research: 1 - water heater with temperature regulator, 2 - water pump, 3 - insulated conductors of calefaction liquid, 4 - water coat with temp. $39^{\circ} \mathrm{C}, 5$ - biofermentor with charge capacity 2 $\mathrm{dm}^{3}, 6$ - sampling tubes, 7 - biogas transporting tube, 8 - gas sampling valve, 9 - biogas volume-scale reservoir.

Methane fermentation experiments were carried out in stirred tank reactors constructed of glass in the Laboratory of Ecotechnologies. General rules for chamber work were based on the fermentation of organic substrate samples which were put into theglass chambers with $2 \mathrm{dm}^{3}$ capacity. Without oxygen presence and additive of fermentation inoculum the conditions present within the fermentation chamber allowed to create an ideal conditions for methane fermentation of the samples. Fermentors with samples were placed in water with regulated temperature (around $39^{\circ} \mathrm{C}$ ) - similar to the real conditions of biogas plant. Biogas produced in each chamber was transferred to cylindrical store - equalizing reservoirs, filled in with liquid.

\subsection{Biogas measurements}

The volume of the produced gases has been measured every 24 hours. Gas composition has been checked out from at least each $1 \mathrm{dm}^{3}$ of the produced biogas. The concentration measurements of methane, carbon dioxide, oxygen, ammonia and hydrogen sulfide in the produced biogas have been carried out with the use of the absorption sensors working in an infrared and electrochemical sensor line. Consequently, each sample for biogas production was monitored for the gas compounds daily. The volume of biogas production and the methane content of biogas were calculated in the Excel sheet. Gas-monitoring system has been calibrated each week using calibration gases. 


\subsection{Methodology of calculations}

Studies of sewage sludge biogas and methane were carried out in the Ecotechnology Laboratory of the Institute of Biosystems Engineering at the University of Life Sciences in Poznań. The experiments were performed on the basis of internal procedures based on the adopted DIN 38 414-S8 and VDI 4630 standards. A detailed description of the methodology of the performed tests was presented in Cieślik et al. [4].

A computational analysis was conducted to estimate the amount of electricity and heat production. The revenue from the energy sales and the balance of corn silage and sewage sludge were calculated. This paper uses the methodology of calculations presented by Szulc and Dach [20].

The following data were included in the calculation:

- purchase cost of corn silage - PLN 140, according to data provided by the owners of biogas plants using this substrate,

- yellow certificate price - 120 PLN [15],

- green certificate price - 33.55 PLN [1],

- electricity sales price - 169.57 PLN [17],

- heat sales price (calculated on the basis of the price of heat obtained from coal-fired coal furnace).

\section{Result and discussion}

\subsection{Daily gas production}

Figure 2 shows the dynamics of methane production in fermentation reactors with a fermentation mixture content of $1200 \mathrm{~g}$.

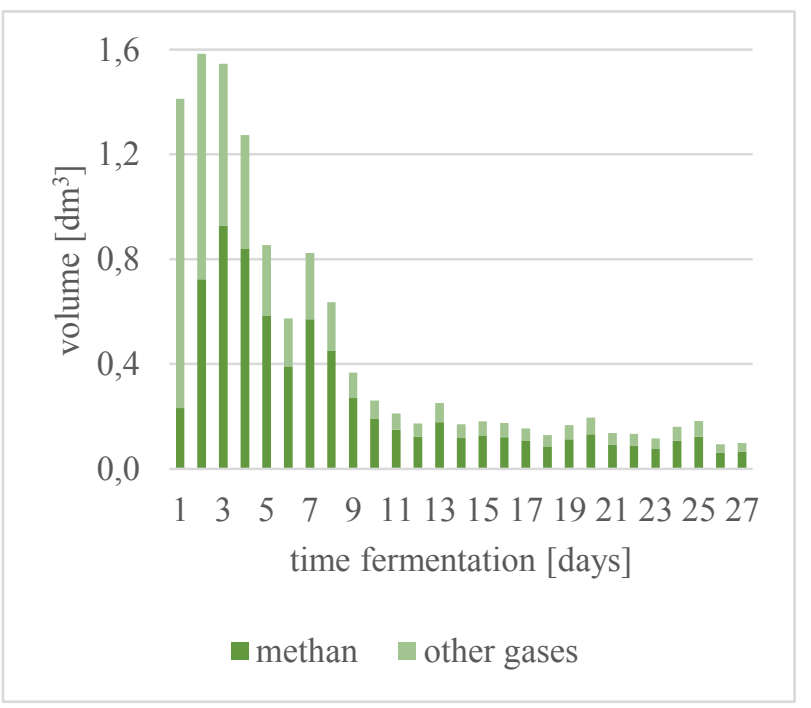

Fig. 2. Daily production of biogas.

The highest production of methane and other gases has already been observed in the second and third day of the experiment, which demonstrates the high content of easily biodegradable components in the recycled substrate.

By analyzing the course of biogas production, the influence of factors inhibiting methane fermentation of sewage sludge is not observed. Therefore, this substrate can be successfully used in biogas plants.

\subsection{Cumulative emissions of methane and biogas}

The following Table 1 summarizes the biogas, methane and methane concentration in biogas from sewage sludge undergoing mesophilic methane fermentation.

Table 1. Content methane, cumulated methane and biogas on dry matter basis.

\begin{tabular}{|l|c|c|}
\hline \multicolumn{1}{|c|}{ Parameters } & Unit & Value \\
\hline Methane percent & {$[\%]$} & 61.27 \\
\hline Cumulated methane & {$\left[\mathrm{m}^{3} \cdot \mathrm{t}^{-1} \mathrm{TS}\right]$} & 160.00 \\
\hline Cumulated biogas & {$\left[\mathrm{m}^{3} \cdot \mathrm{t}^{-1} \mathrm{TS}\right]$} & 261.14 \\
\hline
\end{tabular}

In the mesophilic sludge process, $261.55 \mathrm{~m}^{3}$ of biogas with average methane content of $61.27 \%$ was produced (Table 1), calculated as ton of dry substrate. It is noted that the data collected are close to those of the biogas and methane yields of slurry, which is the basis for methane fermentation in many biogas plants (Table 2).

Table 2. Cumulated biogas and methane of slurry and maize silage.

\begin{tabular}{|l|c|c|c|}
\hline Substrate & $\begin{array}{c}\text { Methane } \\
\text { percent } \\
{[\%]}\end{array}$ & $\begin{array}{c}\text { Cumulated } \\
\text { methane } \\
{\left[\mathrm{m}^{3} \cdot \mathrm{t}^{-1} \mathrm{TS}\right]}\end{array}$ & $\begin{array}{c}\text { Cumulated } \\
\text { biogas } \\
{\left[\mathrm{m}^{3} \cdot \mathrm{t}^{-1} \mathrm{TS}\right]}\end{array}$ \\
\hline Slurry & 77.66 & 208.53 & 268.31 \\
\hline Maize silage & 53.4 & 261.50 & 489.74 \\
\hline
\end{tabular}

On the other hand, the methane and biogas yields obtained are lower than the most commonly used substrate, enriching the fermentation mixture, in the forms of corn silage by 1.63 and 1.88 respectively [4]. Consequently, sludge can only be used as a co-substrate for the fermentation mixture. Another argument for using the substrate to be tested in methane fermentation is the cost of obtaining them.

Table 3. Cost, amount of electricity and heat Energy, revenue from the sale of Energy and heat for sewage sludge and maize silage. 
The presented data demonstrate the high cost of obtaining maize silage for biogas plants. This is due to its many uses and thus becomes a substrate unattractive for biogas plants. In turn, sewage sludge is a substrate that can be obtained for free, due to the possibility of its safe disposal in biogas plants. The presented balance in Table 3 indicates that the total methane fermentation revenue in the case of using sludge is PLN 35.88, whereas in the case of using corn silage the amount of PLN 22.27 is to be paid.

\section{Conclusions}

During the decomposition process under anaerobic sewage sludge, no process inhibitors are observed.

It is possible to dispose of sewage sludge in the methane fermentation process. Its biogas yield makes it a good feedstock for the fermentation mix consisting of other higher yields.

Methane fermentation turns out to be a good solution for the management of sewage sludge. It brings benefits to waste water treatment plant by efficiently disposing of unnecessary waste water treatment products. In addition, biogas plants extract sludge that enrich the fermentation mixture without incurring additional costs.

\section{References}

1. Act on renewable energy sources, art. 43 ust. 3

2. E. Adrjanowicz, M. Janczar, J. Pietkiewicz, Przemysł Fermentacyjny i Owocowo-Warzywny, 10, 20-21(2000)

3. J. Bień, E. Neczaj, M. Worwąg, A. Grosser, D. Nowak, M. Milczarek, M. Janik, Inżynieria i Ochrona Środowiska, 14, 4, 375-384 (2011)

4. M. Cieślik, J. Dach, A. Lewicki, A. Smurzyńska, D. Janczak, J. Pawlicka-Kaczorowska, P. Boniecki, P. Cyplik, W. Czekała, K. Jóźwiakowski, Energy 115(2), 1495-1502 (2016),DOI: 10.1016/j.energy.2016.06.070

5. A.L. Collins, Y.S. Zhang, M. Winter, A. Inman, J.I. Jones, P.J. Johnes, W. Cleasby, E. Vrain, A. Lovett, L. Noble, Science of The Total Environment, 547, 15, 269-281 (2016)

6. W. Czekała, J. Dach, J. Przybył, P. Boniecki, A. Lewicki, P.C.R. Carmona, D. Janczak, H. Waliszewska, Proceedings of the 2nd International Conference on Energy \& Environment: Bringing Together Engineering and Economics, 547-553 (2015), ISBN: 978-989-97050-4-3

7. W. Czekała, S. Bartnikowska, A. Lewicka, A. Bugała, Z. Zbytek, A. Lewicki,3rd International Conference on Structural Nonlinear Dynamics and Diagnosis,83,04005 (2016), DOI: 10.1051/ matecconf/20166004005

8. W. Czekała, A. Smurzyńska, M. Cieślik, P. Boniecki, K. Kozłowski, Energy And Clean

\begin{tabular}{|l|c|c|c|}
\hline \multicolumn{1}{|c|}{ Volume } & Unit & $\begin{array}{c}\text { Sewage } \\
\text { sludge }\end{array}$ & $\begin{array}{c}\text { Maize } \\
\text { silage }\end{array}$ \\
\hline $\begin{array}{l}\text { Cost of } \\
\text { substrate }\end{array}$ & $\mathrm{PLN}$ & 0 & 140 \\
\hline $\begin{array}{l}\text { Amount of } \\
\text { electricity }\end{array}$ & $\mathrm{MWh} \cdot \mathrm{t}^{-1} \mathrm{FM}$ & 0.08 & 0.28 \\
\hline $\begin{array}{l}\text { Amount of heat } \\
\text { energy }\end{array}$ & $\mathrm{MWh} \cdot \mathrm{t}^{-1} \mathrm{FM}$ & 0.10 & 0.31 \\
\hline $\begin{array}{l}\text { Revenue from } \\
\text { the sale of } \\
\text { electricity }\end{array}$ & $\mathrm{PLN} \cdot \mathrm{t}^{-1} \mathrm{FM}$ & 27.17 & 89.15 \\
\hline $\begin{array}{l}\text { Revenue from } \\
\text { the sale of heat }\end{array}$ & $\mathrm{PLN} \cdot \mathrm{t}^{-1} \mathrm{FM}$ & 8.71 & 28.58 \\
\hline Balance & $\mathrm{PLN} \cdot \mathrm{t}^{-1} \mathrm{FM}$ & +35.88 & -22.27 \\
\hline
\end{tabular}

Technologies Conference Proceedings, III, 227233 (2016)

9. A. Grobelak, A. Placek, A. Grosser, Bal Ram Singh, R. A. Åsgeir, A. Napora, M. Kacprzak, Journal of Cleaner Production, 155, 1, 189-197 (2017), DOI: 10.1016/j.jclepro.2016.10.005

10. K. Gorazda, B. Tarko, Z. Wzorek, H. Kominko, A.K. Nowak, J. Kulczycka, A. Henclik, M. Smol, Environmental Research, 154, 171-180(2017)

11. DIN 38 414, Bestimmung des Faulverhaltens "Schlamm und Sedimente" (BeuthVerlag GmbH, Berlin, 1985)

12. M. Gizińska-Górna, W. Czekała, K. Jóźwiakowski, A. Lewicki, J. Dach, M. Marzec, A. Pytka, D. Janczak, A. Kowalczyk-Juśko, A. Listosz, Ecological Engineering, 95, 534-541 (2016),DOI:10.1016/j.ecoleng.2016.06.055.

13. E.Z. Harrison, S.R. Oakes, M. Hysell, A. Hay, Sci. Total Environ.,367, 481-497 (2006)

14. K. Ignatowicz, Environmental Research, 156, 19-22 (2017)

15. Information of the President of the Energy Regulatory Office No. 26/2016 on unitary substitute fees for cogeneration in force in 2017

16. Leclerc, A. Laurent, Science of The Total Environment, 590-591, 452-460 (2017)

17. Energy Law 2017. Information (No 6/2017) on the average quarterly price of electricity sold on terms other than those resulting from Art. 49a sec. 1 and 2 of the Act

18. G.S. Petkov, G.S. Kostadinova, S.A. Denev, G.S. Mihaylova, D.C. Pavlov, Applied Soil Ecology, 34, 1, 10-18 (2006)

19. Regulation of the Minister of Economy of 16 July 2015 on the acceptance of waste for landfill. OJ 2015 pos. 1277.

20. R. Szulc, J.Dach, F. Adamczyk, D. Janczak, J. Lenarczyk, I. Rzeźnik, W. Rzeźnik, Z. Zbytek, Polskie Towarzystwo Inżynierii Rolniczej w Krakowie, $72-79$ (2014)

21. K. Szwedziak, Inżynieria Rolnicza, 4, 297-302 (2006) 
22. T.P. Thomsen, Z. Sárossy, J. Ahrenfeldt, U.B. Henriksen, F.J. Frandsen, D.S. Müller-Stöver, Journal of Environmental Management, 198, 1, 308-318 (2017)

23. X. Yang, Q. Li, Z. Tang, W. Zhang, G. Yu, Q. Shen, F.-J. Zhao, Waste Management, 64, 333-339 (2017)

24. H. Wang, Y. Dong, Y. Yang, G. S. Toor, X. Zhang, Journal of Environmental Sciences, 25, 12, 2435 $2442(2013)$ 